\title{
Az örszemnyirokcsomó-áttét kimutatása 4 mm-nél vastagabb melanomában esélyt ad ígéretes adjuváns kezelésre
}

\author{
Kocsis Ádám dr. ${ }^{\text {* }}$ - Mezőlaki Noémi dr. ${ }^{\text {* }}$ - Porkoláb Dorottya dr. ${ }^{1}$ \\ Mohos Gábor dr. ${ }^{1}$ - Kis Erika dr. ${ }^{1}$ - Varga János dr. ${ }^{1}$ - Baltás Eszter dr. ${ }^{1}$ \\ Ócsai Henriette dr. ${ }^{1}$ - Korom Irma dr. ${ }^{1}$ - Varga Erika dr. ${ }^{1}$ \\ Németh István Balázs dr. ${ }^{1}$ - Kemény Lajos dr. ${ }^{1}$. Oláh Judit dr. ${ }^{1,2}$ \\ `Szegedi Tudományegyetem, Általános Orvostudományi Kar, Bőrgyógyászati és Allergológiai Klinika, Szeged \\ ${ }^{2}$ Szegedi Tudományegyetem, Általános Orvostudományi Kar, Onkoterápiás Klinika, Szeged
}

\begin{abstract}
Bevezetés: Az örszemnyirokcsomó-biopszia (SNB) jelentősége az elörehaladott - 4 mm-nél vastagabb - melanomák kezelésében eddig vitatott volt a szakirodalomban. Manapság azonban az adjuváns terápiák alkalmazásának előfeltétele a regionális nyirokcsomók érintettségének szövettani igazolása. Ugyanakkor az SNB szükségességének kritériumai Magyarországon sem egységesek, van, ahol jelenleg a vastag melanomák esetén nem végzik el ezt a beavatkozást. Célkitüzés: Klinikánkon az elmúlt években konzekvensen elvégeztük az őrszemnyirokcsomók vizsgálatát 4 mm-nél vastagabb melanomák esetén is, így érdemesnek tartottuk értékelni, hogy ebben a betegcsoportban milyen arányban fordul elő a tájéki nyirokcsomók klinikailag nem, szövettanilag viszont detektálható áttéte.

Módszer: A klinikánkon 2007 és 2011 között melanomával diagnosztizált 1133 beteg közül kiválasztottuk azokat a pácienseket, akiknek $4 \mathrm{~mm}$-nél vastagabb primer tumoruk volt, és retrospektíven értékeltük a betegek demográfiai adatait, primer daganatuk klinikai, valamint szövettani jellegzetességeit az őrszemnyirokcsomó szövettani paramétereinek függvényében.

Eredmények: Az 5 éves időszakban 116 olyan, melanomában szenvedő beteget diagnosztizáltunk, akinél vastag melanoma került sebészi kimetszésre. 78 páciensnél történt SNB, mely 50 esetben szövettanilag pozitívnak bizonyult. A betegek átlagos életkora közel 58 év volt.

Következtetés: Klinikánkon évente tíz olyan, vastag melanomás beteget kezelünk, akinél az örszemnyirokcsomó szövettani pozitivitása alapján igazoltuk a betegség metastaticus stádiumát. Eredményeink és a Nemzeti Rákregiszter adatai alapján akár 100 körülire becsülhető azoknak a pácienseknek a száma Magyarországon, akiknél ezzel a patológiai stádiumot meghatározó módszerrel az adjuváns kezelés szükségessége megállapítható. A betegcsoport fiatal életkorát figyelembe véve, hatékony target/immunterápia adjuváns alkalmazásával eredményesebben csökkenthető lehet az elvesztett életévek száma, mint a belszervi metastaticus stádiumban megkezdett kezelésekkel.

Orv Hetil. 2020; 161(39): 1675-1680.
\end{abstract}

Kulcsszavak: 4 mm-nél vastagabb melanoma, őrszemnyirokcsomó-biopszia, adjuváns kezelés

\section{Detection of sentinel lymph node metastasis in thick melanoma provides promising adjuvant treatment}

Introduction: The importance of sentinel lymph node biopsy in the treatment of thick melanomas (Breslow $>4 \mathrm{~mm})$ has so far been debated in the literature. Nowadays, histological verification of regional lymph node involvement is a prerequisite for adjuvant therapy. At the same time, the criteria for the need for sentinel lymph node biopsy are not uniform in Hungary either, there are institutes where this procedure is not performed in the case of thick melanomas. Aim: We have consistently performed sentinel lymph node biopsies in the case of melanomas thicker than 4 mm over a five-year long period at the Department of Dermatology and Allergology of the University of Szeged in order to investigate the proportion of clinically occult regional lymph node metastases present in south-east Hungary.

*A szerzők egyenlő mértékben járultak hozzá a cikk megszületéséhez. 
Method: Out of 1133 patients diagnosed with cutaneous melanoma between 2007 and 2011 in our department, patients with primary melanomas thicker than $4 \mathrm{~mm}$ were retrospectively evaluated based on demographic data, clinical and histological features of the primary tumor correlated with the sentinel lymph node status.

Results: During the 5-year period, 116 patients were diagnosed with thick melanoma and underwent surgical excision. Sentinel lymph node biopsy was performed in the case of 78 patients, which was found to be histologically positive in 50 cases. The mean age of patients was 58 years.

Conclusion: Annually 10 patients with thick melanoma are treated in our department whose regional lymph node metastasis is verified by sentinel lymph node biopsy. Based on our results and the data from the National Cancer Registry, the annual number of patients where adjuvant therapy would be necessary depending on sentinel lymph node positivity is estimated to be up to 100 in Hungary. Given the relatively young mean age of the patient population, the use of adjuvant target/immunotherapy may be more effective in increasing overall survival compared to when treatment is only initiated upon visceral metastases.

Keywords: thick melanoma, sentinel lymph node biopsy, adjuvant treatment

Kocsis Á, Mezólaki N, Porkoláb D, Mohos G, Kis E, Varga J, Baltás E, Ócsai H, Korom I, Varga E, Németh IB, Kemény L, Oláh J. [Detection of sentinel lymph node metastasis in thick melanoma provides promising adjuvant treatment]. Orv Hetil. 2020; 161(39): 1675-1680.

(Beérkezett: 2020. április 6.; elfogadva: 2020. május 3.)

\section{Rövidítések}

AJCC $=$ (American Joint Committee on Cancer) Amerikai Rákellenes Vegyes Bizottság; BRAF = (rapidly accelerated fibrosarcoma isoform B) rapidan gyorsuló fibrosarcoma B-izoformája; $\mathrm{CI}=$ (confidence interval) konfidenciaintervallum; GDPR $=($ General Data Protection Regulation $)$ az Európai Unió általános adatvédelmi rendelete; $\mathrm{HR}=$ (hazard ratio) kockázati arány MEK $=$ MAPK $/$ ERK kináz $; \mathrm{PDl}=($ program med death 1) programozott halál-1; PDLl = PDl-ligand; RAF $=($ rapidly accelerated fibrosarcoma $)$ rapidan gyorsuló fibrosarcoma; RFS = (recurrence-free survival) kiújulásmentes túlélés; $\mathrm{SNB}=$ (sentinel lymph node biopsy) örszemnyirokcsomóbiopszia; $\mathrm{TNM}=$ tumor, nodus, metastasis

Az elmúlt néhány évtizedben a melanoma kezelésében paradigmaváltás történt. Az emlődaganatos betegek kezeléséhez hasonlóan, a mechanikus szemléletet felváltotta a biológiai megközelítés a melanoma sebészi ellátásában is. A korábban alkalmazott agresszív, $5 \mathrm{~cm}$ széles biztonsági zónával történő eltávolítást felváltotta standard kezelésként a tumorvastagsághoz igazodó, maximum $2 \mathrm{~cm}$ ép szegéllyel történő kimetszés [1]. Az 1990-es évek a regionális nyirokcsomók ellátásának szemléletében is jelentős változást hozott: a preventív radikális regionális blokkdissectio helyett az ôrszemnyirokcsomó-biopszia (SNB) szövettani eredménye alapján szelektált blokkdissectio jelent meg a kezelési palettán [2]. Mivel az őrszemnyirokcsomó szövettanilag igazolt daganatos érintettsége ma is az egyik legfontosabb prediktor a túlélésre vonatkozóan, az SNB-t elsősorban a patológiai stádiumot a legpontosabban meghatározó módszerként tartják számon a melanoma vonatkozásában [3]. E beavatkozás elvégzésének indikációja az évtizedek során többször változott, mivel főképpen a közepes kockázatú - 1-4 mm abszolút vastagságú - primer melanomák esetén igazolták kedvező hatását a teljes túlélésre vonatkozóan [4].

Az $1 \mathrm{~mm}$ alatti vékony és a $4 \mathrm{~mm}$ feletti vastag melanomák esetén az SNB elvégzésének szükségességéről évtizedek óta vita zajlik az irodalomban. Legújabban azt is megkérdőjelezik, hogy szükséges-e egyáltalán a blokkdissectio radikális kiterjesztése az SNB szövettani pozitivitása esetén. Manapság egyre több, magasabb szintú evidencia támasztja alá azt a tényt, hogy a nagy morbiditású radikális blokkdissectio nem javítja szignifikánsan sem a teljes, sem a progressziómentes túlélést a melanomás betegeknél $[5,6]$. A nyirokrégió radikális sebészi kezelése helyett mindinkább a szisztémás terápiák kerülnek előtérbe.

A melanoma modern adjuváns kezelésének indikációja az SNB szövettani eredményének ismerete nélkül nem állítható fel, így egyre inkább felértékelődik e stádiummeghatározó metodika az irányelvek alapján. Korábban az egyedüli adjuváns kezelést az interferon-alfa- $2 \mathrm{a}$ és $-2 \mathrm{~b}$ alkalmazása jelentette, melyek alkalmazhatók voltak csupán a tumorvastagság ismeretében is, 2020-tól azonban mindkét szer forgalmazását visszavonták. Manapság a III. stádium, azaz a regionális nyirokcsomóáttét igazolása az előfeltétele mind a célzott, mind az immunonkológiai adjuváns terápiáknak.

Magyarországon a betegség kezelése rendeletileg meghatározott bőronkológiai központokhoz van kötve, ennek ellenére a melanoma sebészi ellátása sajnos nem tekinthetô standardizáltnak, ugyanis a melanoma ellátására kijelölt központok sebészi szemlélete sem teljesen egységes. Vannak olyan centrumok, ahol a $4 \mathrm{~mm}$-nél vastagabb melanomák kezelésében zömmel mellőzték az SNB elvégzését. Mivel ebben a betegcsoportban igen magas a távoli metastasisképződés veszélye, felértékelődik ezeknél a betegeknél a mihamarabbi szisztémás keze- 
lés alkalmazása. A jelenleg rendelkezésre álló klinikai adatok alapján a hatékony adjuváns célzott és immunkezelések indikációjának felállítására a klinikailag okkult nyirokcsomó-metastasisok kimutatása az egyedüli lehetőség, így az SNB elmaradása jelentősen csökkenti a beteg túlélési esélyét.

A hazai helyzet ismeretében felmerült bennünk a kérdés, hogy az SNB elmaradása a magas metastaticus kockázatú, vastag melanomában szenvedő betegek körében vajon hány betegnél okozhatja a modern adjuváns kezelés lehetőségének elvesztését. Tekintettel arra, hogy a Szegedi Tudományegyetem Bőrgyógyászati és Allergológiai Klinikáján az SNB-t konzekvensen elvégeztük az évek során azoknál a melanomás pácienseknél is, akik 4 mm feletti tumorvastagságú primer melanomában szenvedtek, érdemesnek tartottuk retrospektív módon értékelni az őrszemnyirokcsomó(k) pozitivitásának arányát ebben a magas kockázatú betegcsoportban. A jelen közleményben ezeket az eredményeinket összegezzük.

\section{Betegek és módszer}

Retrospektív vizsgálatunk keretében áttekintettük a 2007 és 2011 közötti 5 éves periódusban klinikánkon újonnan diagnosztizált, $4 \mathrm{~mm}$ feletti tumorvastagságú melanomás betegek adatait. Az értékelt paraméterek olyan prognosztikai faktorokra terjedtek ki, mint a páciens neme, életkora, Breslow-féle tumorvastagsága, az őrszemnyirokcsomó lokalizációja és szövettani eredménye. Az adatokat az intézet MedSol-adatbázisából nyertük a hatályos etikai és GDPR-szabályozásnak megfelelően (etikai engedély: MEL-RETRO-001:3521, 40/2015 SZTE). Az eredmények értékelésében Fisher-féle egzakt tesztet és Mann-Whitney-tesztet alkalmaztunk.

\section{Eredmények}

A 2007. január 1. és 2011. december 31. közötti periódust áttekintve, Intézetünkben 1133 betegnél diagnosztizáltunk melanomát, ebből 116 betegnél volt vastag (Breslow $4 \mathrm{~mm}$ feletti) a primer tumor (10\%). A vastag melanomás betegek közül 9 esetben a hiányos adatok miatt (például a primer tumor eltávolítását követően a beteget elvesztettük a követés alól, a szövettani mintát konzultáltuk más intézetből, stb.) kényszerültünk a pácienst az elemzésből törölni, így a jelen kutatásunkban 107 beteg anyagát dolgoztuk fel. A vizsgálatból nyert adatainkat az 1. táblázatban foglaljuk össze. SNB 78 esetben történt. Tapintható metastaticus nyirokcsomó jelenléte 19 páciensnél már eleve feleslegessé tette az SNB vizsgálatát, továbbá 7 betegnél a társbetegségek/ magas életkor miatt nem volt lehetőség a beavatkozás elvégzésére. 2 beteg esetében technikai okból sikertelen volt az SNB, l beteg pedig elutasította a beavatkozást. A vastag melanomában szenvedők $(\mathrm{n}=107)$ átlagos életkora a diagnózis idején 60,97 év volt, míg az SNB-ra kerülőknél ( $\mathrm{n}=78$ ) ez valamivel kevesebbnek, 57,89 év-
1. táblázat $\mid A z S N B$ eredményei a vizsgált paraméterek függvényében

\begin{tabular}{|c|c|c|c|c|}
\hline & SNB-negatív & SNB-pozitív & Összesen & $\mathrm{p}$ \\
\hline Betegszám (fó) & $28(35,89 \%)$ & $50(64,1 \%)$ & $78(100 \%)$ & \\
\hline Átlagéletkor (év) & 58,36 & 57,1 & 57,55 & $0,501 \mathrm{a}$ \\
\hline $\begin{array}{l}\text { Átlagéletkor férfi } \\
\text { (év) }\end{array}$ & 53,94 & 56,05 & 55,06 & $0,739 \mathrm{a}$ \\
\hline Átlagéletkor nő (év) & 65,18 & 57,74 & 59,69 & $0,025 \mathrm{a}$ \\
\hline Férfiak száma (fó) & $11(27 \%)$ & $31(73 \%)$ & 42 & \\
\hline Nők száma (fö) & $17(48 \%)$ & $19(52 \%)$ & 36 & $0,062 \mathrm{~b}$ \\
\hline $\begin{array}{l}\text { Primer tumor a } \\
\text { fej-nyak tájékon }\end{array}$ & $2(50 \%)$ & $2(50 \%)$ & 4 & \\
\hline $\begin{array}{l}\text { Primer tumor a } \\
\text { törzsön }\end{array}$ & $12(32 \%)$ & $25(67 \%)$ & 37 & \\
\hline $\begin{array}{l}\text { Primer tumor a } \\
\text { végtagokon, illetve } \\
\text { a váll- és medence- } \\
\text { övön }\end{array}$ & $14(38 \%)$ & $23(62 \%)$ & 37 & $0,681 \mathrm{~b}$ \\
\hline $\begin{array}{l}\text { A Breslow-féle } \\
\text { tumorvastagság } \\
\text { átlaga }(\mathrm{mm})\end{array}$ & 6,671 & 6,254 & 6,4 & $0,237 \mathrm{a}$ \\
\hline Clark I. & 0 & 0 & 0 & \\
\hline Clark II. & $2(50 \%)$ & $2(50 \%)$ & 4 & \\
\hline Clark III. & $9(30 \%)$ & $21(70 \%)$ & 30 & \\
\hline Clark IV. & $10(29 \%)$ & $24(71 \%)$ & 34 & \\
\hline Clark V. & $7(70 \%)$ & $3(30 \%)$ & 10 & $0,089 \mathrm{~b}$ \\
\hline Ulceratio & $8(25 \%)$ & $24(75 \%)$ & 32 & \\
\hline Nem ulcerált & $20(43 \%)$ & $26(57 \%)$ & 46 & $0,149 \mathrm{~b}$ \\
\hline
\end{tabular}

$\mathrm{a}=$ Mann-Whitney-teszt; $\mathrm{b}=$ Fisher-féle egzakt teszt; SNB = őrszemnyirokcsomó-biopszia

nek bizonyult, ami korrelál azzal, hogy 7 páciensnél a magas életkor (>80 év) miatt a beavatkozást nem végeztük el. Az SNB-n átesett betegeknél nem volt lényeges különbség a szövettanilag pozitív (57,64 év), illetve negatív (58,769 év) páciensek életkorában. Az őrszemnyirokcsomók ( $\mathrm{n}=88$ ) lokalizációja a következő eloszlást mutatta a vizsgált betegekben: a hónaljban 51 (57,9\%), a lágyékhajlatban $24(27,2 \%)$, a nyakon $6(6,8 \%)$ esetben került azonosításra. Ettől eltérő, ún. atípusos ôrszemnyirokcsomót 4 páciensnél a térdhajlatban és további 3 esetén egyéb, ún. in tranzit lokalizációban a háton detektáltunk.

A 78, SNB-n átesett beteg közül 28 (36\%) esetben szövettanilag nem volt detektálható melanomametastasis, míg 50 páciens (64\%) esetében a hisztológia igazolta a nyirokcsomóáttétet. Ez az esetek közel kétharmadát jelenti, ami igen magas arány. Az utóbbi 50 beteg az SNB elvégzését követően a jelenleg érvényben lévő AJCC (American Joint Committee on Cancer) TNM 8. verziója alapján a stage III.C kategóriába sorolható. Az átlagos Breslow-féle tumorvastagság a magas kockázatú melanomában szenvedőknél $(\mathrm{n}=107) 6,79 \mathrm{~mm}$, az őr- 
szemnyirokcsomó-mútétre kerülóknél $(\mathrm{n}=78)$ 6,40 $\mathrm{mm}$, az SNB-pozitív esetekben $6,254 \mathrm{~mm}$, míg a szövettanilag negatív pácienseknél $6,671 \mathrm{~mm}$ volt.

Mútéti szövődményként 17 betegnél $(21,7 \%)$ detektáltunk eltérést, mely elsősorban seroma $(\mathrm{n}=10)$ és infekció $(\mathrm{n}=3)$ volt.

\section{Megbeszélés}

A vizsgált 5 éves időszakban 1133, melanomában szenvedő beteget kórisméztünk és kezeltünk a Szegedi Tudományegyetem Börgyógyászati és Allergológiai Klinikáján, ami a Nemzeti Rákregiszter adatai szerint ugyanebben a periódusban Magyarországon újonnan diagnosztizált 9862 melanomás beteg egytizede [7].

Intézetünk a Dél-alföldi régió dermatoonkológiai betegeinek ellátásáért felelős központ. Fontos megjegyezni, hogy Bács-Kiskun megyében a melanomás betegek sebészeti ellátásából a kecskeméti megyei kórház jelentős mértékben és a szakmai elvárásoknak maximálisan megfelelve veszi ki a részét. A szisztémás kezelések meghatározását az általuk kezelt betegek többségénél azonban klinikánk bőronkológiai multidiszciplináris teamje végzi.

A fenti időszakban a három megyében (Bács-Kiskun, Csongrád és Békés) 1268, újonnan felismert melanomás beteget jelentettek a Nemzeti Rákregiszterbe; közülük a páciensek 90\%-át klinikánkon kezeltünk, így elmondhatjuk, hogy adataink alkalmasak régiónk helyzetének értékelésére a melanoma sebészi ellátása terén. A klinikánkon kezelt melanomás betegek adataira támaszkodó becslés szerint évente akár 100 olyan, előrehaladott, $4 \mathrm{~mm}$ feletti abszolút vastagságú melanomában szenvedő beteg lehet az országban, akiknél az SNB elvégzése alapján az adjuváns kezelés szükségessége megállapítható, illetve várhatóan magasabb hatékonysággal kezdhetô meg innovatív szerekkel az adjuváns terápia.

A molekuláris ismeretek gyarapodása révén az ezredforduló után ismertté vált, hogy a melanomák nagyobb hányadában a RAF-MEK-ERK jelátviteli út alterációi játszanak szerepet e daganat kialakulásában [8].

A BRAF-gén V600-as mutációját hordozó metastaticus melanomában szenvedő betegeknél a BRAF-MEK inhibitorok számítanak manapság standard kezelésnek. A $B R A F$ vad típusú áttétes tumorok esetén az immunterápia az elsődleges kezelés, ezen belül a PDl-gátló terápiák a preferáltak $[9,10]$.

A fenti kezelések hatására jelentősen javultak a melanomás betegek túlélési esélyei, napjainkban minden harmadik, metastaticus melanomával kezelt beteg még 5 év múlva is életben van, ami a korábbi igen szerény, átlagosan néhány hónapos túléléshez képest jelentős előrelépés.

Az utóbbi évek klinikai kutatásai a nem operálható áttétes betegek kezelésén túl megváltoztatták a melanoma adjuváns kezelését is. A magas kockázatú melanoma ipilimumab adjuváns kezelésére vonatkozó kedvező progressziómentes túlélési adatokról 2016-ban jelent meg az első közlemény, azonban a magas, grade 3 . vagy annál súlyosabb mellékhatásráta $(45,9 \%)$ miatt e kezelés nem terjedt el [11].

A 'CheckMate 238' III. fázisú vizsgálatban az adjuváns nivolumab hatékonyságát és biztonságosságát $\mathrm{az}$ ipilimumab adjuváns terápiával hasonlították össze III/B, III/C vagy IV. stádiumú melanomás betegekben. A III/B és III/C stádiumú betegek körében a 12 hónapos, kiújulásmentes túlélés (RFS) 72,3\% volt nivolumabterápia mellett, míg 61,6\%-nak bizonyult ipilimumabnál; mindez a IV. stádiumú betegcsoportban $63,0 \%$-os, illetve $57,5 \%$-os arányt mutatott [12].

A COMBI-AD volt az első olyan prospektív, III. fázisú vizsgálat, amelynek során bizonyították, hogy a 12 hónapos adjuváns BRAF-MEK inhibitor kezelés szignifikánsan javította a RFS-t placebokontroll mellett V600-as mutációt mutató, harmadik stádiumban lévő melanomás betegeknél teljes reszekciót követően. Az eredmények szerint a dabrafenib-trametinib kombinációs kezelésben részesülő betegcsoportban a becsült 3 éves RFS szignifikánsan magasabb, $58 \%$ volt a placebokar 39\%-ával szemben $(\mathrm{p}<0,001)[13]$.

Eggermont és mtsai 2018-ban közölték az EORTC 1325-ös számú (Keynote 054) randomizált, kettős vak-, III. fázisú klinikai vizsgálat eredményét, melyben a 3 hetenként alkalmazott 200 mg dózisú pembrolizumabterápiát placebokontroll mellett értékelték magas kiújulási kockázattal bíró, hármas stádiumú, reszekált melanoma kezelésében [14].

A fenti klinikai vizsgálatban a betegek TNM-besorolásához az AJCC 7. kiadását vették alapul. Az ennek megfelelően értékelt szövettani eredmények szerint a III/A, B és C stádiumba sorolható, R0-reszekción, valamint őrszemnyirokcsomó-pozitivitást követően komplett regionális blokkdissectión átesett 1019 páciens került randomizáltan, $1: 1$ arányban beválasztásra a vizsgálatba. A III/A stádiumú betegek közül csak azokat vonták be a kezelésbe, akiknél az őrszemnyirokcsomóban kimutatott melanomaáttét mérete a legnagyobb átméröjében meghaladta az $1 \mathrm{~mm}$ nagyságot. 18 alkalommal, közel egy éven át kaptak a betegek pembrolizumab- vagy placebokezelést, illetve mindaddig, amíg nem jelentkezett kiújulás vagy nem tolerálható mellékhatás. 15 hónap átlagos követési idő után értékelve az adatokat azt találták, hogy a pembrolizumab szignifikánsan növelte a RFS-t a placebokezeléssel szemben. Az l éves RFS pembrolizumab mellett 75,4\% (95\% konfidenciaintervallum [CI], 71,378,9 ) volt, míg 61,0\%-nak bizonyult a placebóval kezelt csoportban $(95 \%$ CI, 56,5-65,1). A betegség kiújulására és/vagy halálra vonatkozó kockázatot (HR) 0,57-nak találták $(98,4 \%$ CI $, 0,43-0,74 ; \mathrm{p}<0.001)$. Alcsoportanalízisben annál a 853 páciensnél, akiknek PDLl-pozitív tumoruk volt, az 1 éves RFS némileg magasabbnak bizonyult $(77,1 \%$ [95\% CI, 72,7-80,9]), mint a teljes, pembrolizumabbal kezelt csoportban. A pembrolizumabnak a progressziómentes túlélésre gyakorolt kedvező hatása mind a $B R A F$-vad, mind a $B R A F$-mutáns 
csoportban megfigyelhető volt. Súlyos mellékhatásokat (grade 3-5.) a pembrolizumabbal kezelt csoportban 14,7\%-ban, míg placebo mellett 3,4\%-ban észleltek.

Vizsgálatunkban a vastag melanomában szenvedő betegeink átlagos életkora 60 év körül van, ami jelzi, hogy ebben a betegcsoportban várhatóan magas az elvesztett életévek száma, azaz a hatékony adjuváns kezelések létjogosultsága jelentős nemcsak az egyén érdekében, hanem gazdasági szempontból is.

A melanomában szenvedő betegeink egytizedénél észlelhető 4 mm-nél nagyobb tumorvastagság, melynek átlaga $6,79 \mathrm{~mm}$-nek adódott a vizsgált betegcsoportban. Az egyik legfrissebb publikációban argentin szerzők értékelték vastag melanomában szenvedő betegeiknél SNB-s eredményeiket. Vizsgálataikban a melanomás páciensek 6,7\%-ában észleltek vastag tumort, ami alacsonyabb arány a klinikánkon kezelt, vastag melanomás betegek 10\%-ához képest [15].

A vastag tumorok aránya régiónkban változatlanul magas. Mivel a melanoma klinikai jelei szabad szemmel felismerhetők, a bőrdaganatok gyanújeleiről a laikusok széles körű felvilágosítása nélkülözhetetlen a jövőben is.

Vizsgálatunkban betegeink közel kétharmadában (64\%) igen magas arányban észleltünk pozitív őrszemnyirokcsomót, ami a különböző irodalmi adatok szerint 22-64\% között, széles skálán mozog [16-19].

A fent említett vizsgálatban Otero és mtsai $56 \%$-ban észleltek vastag melanomában őrszemnyirokcsomó-pozitivitást [15].

Kachare és mtsai 2746, vastag melanomás beteg SNBeredményének vizsgálatakor 32,2\%-os pozitivitást találtak [20], Ribero és mtsai 47,1\%-os arányról számoltak be [21], míg Vermeeren és mtsai kisebb esetszámú vizsgálatukban a mi eredményeinkhez hasonló, $64,5 \%$-os pozitív SNB-arányt írtak le [22].

Mindazonáltal számos tanulmány megerősíti az SNB szerepét a vastag melanomák kezelésében, melynek szignifikáns szerepe van a betegségspecifikus túlélés, a relapsusmentes időszak hossza, valamint az össztúlélés tekintetében [23-25].

A vastag melanomák esetén a legfóbb kifogás, mely az SNB elhagyását támogatja, hogy ezeknél a tumoroknál fóleg a betegség hematogén terjedése a kórlefolyás meghatározója, és ezen kutatók szerint az SNB elvégzése nem befolyásolja sem a kiújulást, sem a mortalitást [26].

Ellenérvként merül fel továbbá a beavatkozás okozta morbiditás, és az erre vonatkozó szakirodalom is igen megosztott: 1,8\% és 33\% közötti szövődmény-előfordulási adatokról találhatók beszámolók [27].

Jelen vizsgálatunkban 21,8\%-ban észleltük mütéthez kapcsolható komplikációként zömmel seroma és infekció létrejöttét, ami átlagosnak tekinthető. Oana-Diana Persa és mtsai 615, SNB-n átesett beteg esetében átlagosan 115 hetes utánkövetéssel vizsgálták a posztoperatív seromaképződés és az egyéb szövődmények gyakoriságát. Vizsgálatukban a betegek 20,4\%-ánál volt észlelhető valamilyen szövődmény. A leggyakoribb, SNB-hez társu- ló morbiditás esetükben a posztoperatív seromaképződés volt, az esetek 19,6\%-ában fordult elö, és szignifikánsan gyakrabban fordult elő a lágyékhajlatban, valamint férfiak esetében [28].

Espinosa-Pereiro munkacsoportja 124, SNB-n átesett beteg 52,5 hónapos utánkövetéses vizsgálatában a betegek 30,9\%-ánál észlelt a mútéttel kapcsolatos valamilyen morbiditást. Vizsgálatukban a leggyakoribb problémák a hegesedés és a sebinfekció voltak (10-10\%), míg seromaképződés és lymphoedema az esetek 5-5\%-ában volt észlelhető [29].

\section{Következtetés}

Eredményeinket összegezve elmondhatjuk, hogy régiónkban magas mind a vastag melanomák, mind az őrszemnyirokcsomó-pozitivitás aránya. Mivel a szegedi klinikán az évente Magyarországon újonnan diagnosztizált melanomás esetek kb. tizedét látjuk el, országosan a vastag primer melanomás betegszám akár tízszeres is lehet, így a pontos patológiai stádiummeghatározást elősegítő SNB-becslésünk szerint hazai viszonylatban évente akár 100 páciensnél nélkülözhetetlen lehet az optimális kezelés érdekében. Mindezen adatok tovább erósítik azt a törekvést, hogy a melanoma sebészi kezelésének csak azokban a központokban van létjogosultsága Magyarországon, ahol az SNB elvégzésének személyi és tárgyi feltételei egyaránt adottak.

Anyagi támogatás: Pályázati támogatás: OTKA Kl25509-2017(N.I.B.), GINOP-2.3.2-15-2016-00020 (N. I. B., K. L., O. J).

Szerzői munkamegosztás: K. Á.: A cikk írása. M. N., P. D.: Statisztikai munka, a betegdokumentáció kutatása. M. G., K. E., V. J.: A betegek sebészi kezelése. B. E., Ó. H.: A betegek onkológiai gondozása. K. I., V. E., N. I. B.: A szövettani vizsgálatok végzése. K. L.: Koordinálás, útmutatás, korrektúra végzése. O. J.: A cikk írása, koordináció, útmutatás, korrektúra végzése. A cikk végleges változatát valamennyi szerző elolvasta és jóváhagyta.

Érdekeltségek: A szerzőknek nincsenek érdekeltségeik.

\section{Irodalom}

[1] Swetter SM, Tsao H, Bichakjian CK, et al. Guidelines of care for the management of primary cutaneous melanoma. J Am Acad Dermatol. 2019; 80: 208-250.

[2] Morton DL, Wen DR, Wong JH, et al. Technical details of intraoperative lymphatic mapping for early stage melanoma. Arch Surg. 1992; 127: 392-399.

[3] Balch CM, Soong SJ, Gershenwald JE, et al. Prognostic factors analysis of 17600 melanoma patients: validation of the American Joint Committee on Cancer melanoma staging system. J Clin Oncol. 2001; 19: 3622-3634. 
[4] Morton DL, Thompson JF, Cochran AJ, et al. Final trial report of sentinel-node biopsy versus nodal observation in melanoma. N Engl J Med. 2014; 370: 599-609.

[5] Delgado AF, Delgado AF. Complete lymph node dissection in melanoma: a systematic review and meta-analysis. Anticancer Res. 2017; 37: 6825-6829.

[6] Stadler R, Leiter U, Garbe C. Lack of survival benefit in sentine lymph node-positive melanoma with immediate complete lymphadenectomy - a review. J Dtsch Dermatol Ges. 2019; 17: 7-13.

[7] Hungarian Cancer Registry. [Magyar Rákregiszter.] Available from: https://onkol.hu/hungarian-cancer-registry/?lang=en [accessed: May 2, 2020]. [Hungarian]

[8] Curtin JA, Fridlyand J, Kageshita T, et al. Distinct sets of genetic alterations in melanoma. N Engl J Med. 2005; 353: 2135-2147.

[9] Michielin O, van Akkooi AC, Ascierto PA, et al. Cutaneous melanoma: ESMO clinical practice guidelines for diagnosis, treatment and follow-up. Ann Oncol. 2019; 30: 1884-1901.

[10] Coit DG, Thompson JA, Albertini MR, et al. Cutaneous melanoma, version 2.2019, NCCN clinical practice guidelines in oncology. J Natl Compr Canc Netw. 2019; 17: 367-402.

[11] Eggermont AM, Chiarion-Sileni V, Grob JJ, et al. Prolonged survival in stage III melanoma with ipilimumab adjuvant therapy. N Engl J Med. 2016; 375: 1845-1855. [Correction: N Engl J Med. 2018; 379: 2185.]

[12] Weber J, Mandala M, Del Vecchio M, et al. Adjuvant nivolumab versus ipilimumab in resected stage III or IV melanoma. N Engl J Med. 2017; 377: 1824-1835.

[13] Long GV, Hauschild A, Santinami M, et al. Adjuvant dabrafenib plus trametinib in stage III $B R A F$-mutated melanoma. N Engl J Med. 2017; 377: 1813-1823.

[14] Eggermont AM, Bank CU, Mandala M, et al. Adjuvant pembrolizumab versus placebo in resected stage III melanoma. N Engl J Med. 2018; 378: 1789-1801.

[15] Rodriguez Otero JC, Dagatti MS, Fernandez Bussy R, et al. Sentinel lymph node biopsy in patients with thick primary cutaneous melanoma. World J Oncol. 2019; 10: 112-117.

[16] Morton DL, Thompson JF, Cochran AJ, et al. Final trial report of sentinel-node biopsy versus nodal observation in melanoma. N Engl J Med. 2014; 370: 599-609.

[17] Yamamoto M, Fisher KJ, Wong JY, et al. Sentinel lymph node biopsy is indicated for patients with thick clinically lymph nodenegative melanoma. Cancer 2015; 121: 1628-1636.
[18] White I, Fortino J, Curti B, et al. Clinical impact of sentinel lymph node biopsy in patients with thick $(>4 \mathrm{~mm})$ melanomas. Am J Surg. 2014; 207: 702-707.

[19] Meguerditchian AN, Asubonteng K, Young C, et al. Thick primary melanoma has a heterogeneous tumor biology: an institutional series. World J Surg Oncol. 2011; 9: 40.

[20] Kachare SD, Singla P, Vohra NA, et al. Sentinel lymph node biopsy is prognostic but not therapeutic for thick melanoma. Surgery $2015 ; 158$ : 662-668.

[21] Ribero S, Osella-Abate S, Sanlorenzo M, et al. Sentinel lymph node biopsy in thick-melanoma patients $(\mathrm{N}=350)$ : what is its prognostic role? Ann Surg Oncol. 2015; 22: 1967-1973.

[22] Vermeeren L, van der Ent FW, Sastrowijoto PS, et al. Thick melanoma: prognostic value of positive sentinel nodes. World J Surg. 2009; 33: 2464-2468.

[23] Bello DM, Han G, Jackson L, et al. The prognostic significance of sentinel lymph node status for patients with thick melanoma. Ann Surg Oncol. 2016; 23(Suppl 5): 938-945.

[24] Hunger RE, Michel A, Seyed Jafari SM, et al. Sentinel lymph node biopsy in thick malignant melanoma: a 16-year single unit experience. Eur J Dermatol. 2015; 25: 472-476.

[25] de Oliveira Filho RS, da Silva AM, de Oliveira DA, et al. Sentinel node biopsy should not be recommended for patients with thick melanoma. Rev Col Bras Cir. 2013; 40: 127-129.

[26] Hettiarachy SP, Kang N, O’Toole G, et al. Sentinel lymph node biopsy in malignant melanoma: a series of 100 consecutive patients. Br J Plast Surg. 2000; 53: 559-562.

[27] Read RL, Pasquali S, Haydu L, et al. Quality assurance in melanoma surgery: the evolving experience at a large tertiary referral centre. Eur J Surg Oncol. 2015; 41: 830-836.

[28] Persa OD, Knuever J, Rose A, et al. Predicting risk for seroma development after axillary or inguinal sentinel lymph node biopsy in melanoma patients. Int J Dermatol. 2019; 58: 185-189.

[29] Espinosa-Pereiro CE, Zulaica Gárate A, García-Doval I. Complications and sequelae after sentinel lymph node biopsy in melanoma: a retrospective cohort study. [Complicaciones y secuelas de la técnica de biopsia selectiva del ganglio centinela para el melanoma en una cohorte retrospectiva.] Actas Dermosifiliogr. 2019; 110: 482-489. [Spanish]

(Kocsis Ádám dr., Szeged, Korányi fasor 6., 6720 e-mail: drkocsisadam@gmail.com)

A cikk a Creative Commons Attribution 4.0 International License (https://creativecommons.org/licenses/by/4.0/) feltételei szerint publikált Open Access közlemény, melynek szellemében a cikk bármilyen médiumban szabadon felhasználható, megosztható és újraközölhető, feltéve, hogy az eredeti szerző és a közlés helye, illetve a CC License linkje és az esetlegesen végrehajtott módosítások feltüntetésre kerülnek. (SID_1) 